\title{
FERMENTATION AND ENZYME TREATMENTS FOR SORGHUM
}

\author{
Patrícia Fernanda Schons ${ }^{1}$, Vania Battestin², Gabriela Alves Macedo ${ }^{1 *}$
}

${ }^{1}$ Universidade de Campinas, Faculdade de Engenharia de Alimentos, Departamento de Ciência de Alimentos, Campinas, SP, Brasil; ${ }^{2}$ Centro Federal de Educação Tecnológica, Valença, RJ, Brasil.

\begin{abstract}
Sorghum (Sorghum bicolor Moench) is the fifth most produced cereal worldwide. However, some varieties of this cereal contain antinutritional factors, such as tannins and phytate that may form stable complexes with proteins and minerals which decreases digestibility and nutritional value. The present study sought to diminish antinutritional tannins and phytate present in sorghum grains. Three different treatments were studied for that purpose, using enzymes tannase (945 U/Kg sorghum), phytase (2640 U/Kg sorghum) and Paecilomyces variotii (1.6 X $10^{7}$ spores $\left./ \mathrm{mL}\right)$; A) Tannase, phytase and Paecilomyces variotii, during 5 and 10 days; B) An innovative blend made of tanase and phytase for 5 days followed by a Pv increase for 5 more days; C) a third treatment where the reversed order of B was used starting with Pv for 5 days and then the blend of tannase and phytase for 5 more days. The results have shown that on average the three treatments were able to reduce total phenols and both hydrolysable and condensed tannins by 40.6, 38.92 and $58.00 \%$, respectively. Phytase increased the amount of available inorganic phosphorous, on the average by $78.3 \%$. The most promising results concerning tannins and phytate decreases were obtained by the enzymes combination of tannase and phytase. The three treatments have shown effective on diminishing tannin and phytate contents in sorghum flour which leads us to affirm that the proposed treatments can be used to increase the nutritive value of sorghum grains destined for either animal feeds or human nutrition.
\end{abstract}

Key words: Fermentation, tannase, phytase, sorghum.

\section{INTRODUCTION}

Tannins belong to a group of phenolic compounds present in the secondary metabolism of plants. These compounds are mostly soluble in water (except those with high molecular weights), and are capable of forming stable complexes with proteins and other polymers such as cellulose, hemi-cellulose, pectin and with minerals (14). Phytate (myo-inositol hexakis phosphate, $\mathrm{IP}_{6}$ ) is the major inhibitor of mineral absorption from plant foods, and decreasing the content of phytic acid in meals of plant origin greatly improves the absorption of minerals (16). Phosphate from phytic acid is poorly available, costly and non-renewable mineral therefore phosphate is commonly added to pork, poultry and fish diets to supply the 
phosphorus to meet nutritional requisites (35).

Several simple processing methods, such as decortication, soaking, cooking, germination, enzymes and fermentation, have been used to reduce the amounts of tannins phenols and phyates $(11,15,21,22,25,35,38)$.

Tannin acyl hydrolases, commonly referred to as tannases (E.C. 3.1.1.20), are inducible enzymes produced by fungi, yeast and bacteria. Tannases have mostly been characterized by their activity upon polyphenolic complexes. They are able to hydrolyze the ester bond (galloyl ester of a moiety alcohol) and the depside bond (galloyl ester of gallic acid) of substrates such as tannic acid, epicatechin gallate, epigallocatechin gallate, and chlorogenic acid which structural compositions are displayed in Fig.1 (12). Tannase has been extensively used in food, beverage and pharmaceutical industries $(29,33)$.

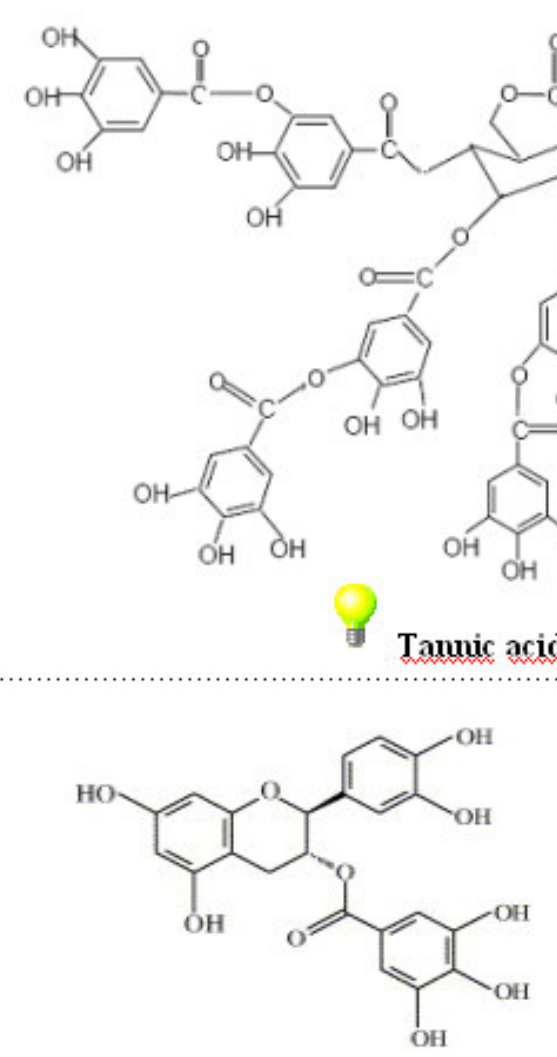

(-) Catechin gallate

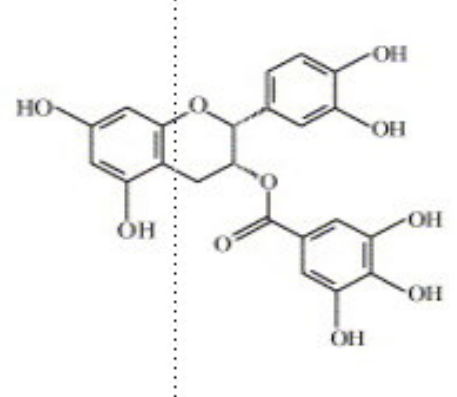

(-) Eicatechin gallate<smiles>O=C(OC1Cc2c(O)cc(O)cc2OC1c1cc(O)c(O)c(O)c1)c1cc(O)c(O)c(O)c1</smiles>

(-) Epigallocatechin gallate

Figure 1. Substrates that tannase can act on (11).

Phytases (EC: 3.1.3.8 or 3.1.3.26) are enzymes that hydrolyze phytate (myo-inositol hexakisphosphate), releasing phosphoric acid, free inositol and/or intermediate compounds such as esters of mono-, bi-, tri-, tetrakis, and pentakisphosphateinositol $\left(\mathrm{IP}_{1} \mathrm{IP}_{5}\right)$, depending on the degree of dephosphorylation and the release of minerals that may be chelated. Thus, the dietary effect of this enzyme is mainly related to improvement in weight gain and the absorption of phosphorus and minerals. Phytic acid is the main storage form of phosphorus in grains, legumes, oilseeds and pollens $(17,24)$. 
Many studies have demonstrated that fermentation processes are an excellent way of diminishing antinutritional factors like tannins and phytate $(34,10)$.

\section{MATERIALS AND METHODS}

\section{Chemicals and reagents}

All reagents used were of analytical grade: methanol (ECIBRA, São Paulo, Brazil), chloride acid (SYNTH, São Paulo, Brazil), Follin-Ciocalteau, vanillin and amoniacal ferric sulphate (VETEC, São Paulo, Brazil), tannic acid to assay tannase activity (MERCK, Darmstad, Germany), tannic acid for fermentation media (Tanal-B - BASF), ( \pm )-catechin and gallic acid (SIGMA, Steinheim, Germany) and dibasic potassium phosphate (ECIBRA, Brazil).

\section{Microorganism Screening}

The Department of Food Science - Unicamp supplied five hundred fungal cultures from its departmental stock culture collection that were then screened for their tannase producing ability. The best tannase producing fungus was identified as $P$. variotii (20). This microorganism was used to treat sorghum gruels and to produce tannase enzyme. The commercial phytase was purchased from BASF (NATUPHOS®, BASF Germany).

\section{Microorganism Preservation for Tannase pre-inoculum Preparation}

A $P$. variotii strain obtained using fungal isolation procedures was used for the production of tannase. The strain was maintained in PDA (potato dextrose agar) slants, stored at $4{ }^{\circ} \mathrm{C}$. The strain was replicated in PDA containing $0.2 \%(\mathrm{w} / \mathrm{v})$ of tannic acid and incubated at $30{ }^{\circ} \mathrm{C}$ for $72 \mathrm{~h}$. The preinoculum was prepared by adding $2.5 \mathrm{~mL}$ of distilled water to remove the spores and obtain a suspension containing $1.6 \times 10^{7}$ spores $/ \mathrm{mL}$.

\section{Fermentation Media for Tannase Production}

An adapted form of the procedure proposed by Battestin
\& Macedo (4) was used to produce the tannase. For the fermentation process, a $500 \mathrm{~mL}$ conical flask was used containing the following mixture: $20 \mathrm{~g}$ of wheat bran, $20 \mathrm{~mL}$ of distilled water and $10 \%$ of tannic acid (w/w). The culture medium ( $\mathrm{pH} \mathrm{5.7)} \mathrm{was} \mathrm{sterilized} \mathrm{at} 120{ }^{\circ} \mathrm{C}$ for $20 \mathrm{~min}$ and the relative humidity of the medium after sterilization remained at $60 \%$ (WB). The flasks were then inoculated with $2.5 \mathrm{~mL}$ of the pre-inoculum suspension and incubated at $30^{\circ} \mathrm{C}$ for $120 \mathrm{~h}$. After fermentation, $160 \mathrm{~mL}$ of $20 \mathrm{mM}$ acetate buffer, $\mathrm{pH} 5.0$ were added and shaken at $200 \mathrm{rpm}$ for $1 \mathrm{~h}$. The solution was filtered and centrifuged at 9,650xg for $30 \mathrm{~min}$ at $4{ }^{\circ} \mathrm{C}$ (Beckman J2-21 Centrifuge, Beckman-Coulter, Inc. Fullerton, CA, USA). The supernatant was then treated with solid ammonium sulphate (80\% saturation) and allowed to stand overnight at $4{ }^{\circ} \mathrm{C}$. The precipitate was collected by centrifugation $(9,650 \mathrm{xg}-30 \mathrm{~min})$, dissolved in distilled water, dialysed against distilled water and lyophilized (LIOTOP L101). The lyophilized preparation was used as crude tannase.

\section{Determination of Tannase Activity}

A colorimetric assay was used to determine tannase activity, based on measuring the residual tannic acid content after the enzymatic reaction (23). The reaction mixture consisted of $0.3 \mathrm{~mL}$ of the tannic acid substrate $(0.7 \%(\mathrm{w} / \mathrm{v})$ in $0.2 \mathrm{M}$ acetate buffer at $\mathrm{pH} 5.5$ ) and $0.5 \mathrm{~mL}$ of the enzyme extract, incubated at $60{ }^{\circ} \mathrm{C}$ for $10 \mathrm{~min}$. The enzymatic reaction was paralysed by the addition of $3 \mathrm{~mL}$ of a bovine serum albumin solution - BSA $(1 \mathrm{mg} / \mathrm{mL})$ that led to the precipitation of the remaining tannic acid. The tubes were than centrifuged at 9,650x $\mathrm{g}$ for $15 \mathrm{~min}$ at $4{ }^{\circ} \mathrm{C}$ and the precipitate dissolved in 3 $\mathrm{mL}$ of SDS-triethanolamine, followed by the addition of $1 \mathrm{~mL}$ of $\mathrm{FeCl}_{3}$ reagent and then $15 \mathrm{~min}$ were allowed for colour stabilization. The absorbance was measured at $530 \mathrm{~nm}$ and the enzyme activity calculated using the change in absorbance at $530 \mathrm{~nm}$. One unit of tannase activity was defined as the amount of tannic acid hydrolysed by $1 \mathrm{~mL}$ of enzyme per minute of reaction): $A b s_{530}=A b s_{\text {control }}-A b s_{\text {test }}$. 


\section{Sorghum Sampling Preparation}

The sorghum grains were produced in the State of Paraná - Brazil and donated by Polinutri Alimentos, São Paulo. They were sorted and washed several times with water, dried at 50 ${ }^{\circ} \mathrm{C}$ for $4 \mathrm{~h}$ and milled to obtain $<60$ mesh flour.

\section{Fermentation and Enzymatic Treatment}

The sorghum flour was boiled with water in a ratio of 1:6 rate (sorghum:water) for $3 \mathrm{~min}$ while stirring. After boiling, the sorghum flour was cooled at room temperature $\left(25^{\circ} \mathrm{C}\right) .10 \mathrm{~g}$ of boiled sorghum flour were introduced into each $50 \mathrm{~mL}$ flask. Treatments applied were carried out with $P$. variotii (suspension containing $1.6 \times 10^{7}$ spores $/ \mathrm{mL}$ ), tannase $(945 \mathrm{U} / \mathrm{g}$ flour) and phytase $(2,640 \mathrm{U} / \mathrm{g}$ flour). Processes applied are illustrated in Fig. 2 and were performed in 3 ways, as follows: a) a combined process, in which the sorghum flour was treated with $P$. variotii, tannase and phytase all together; b) tannase and phytase enzymes (5 days) and subsequent fermentation $(P$. variotii) (5 days); c) fermentation ( $P$. variotii) (5 days) and then enzymatic treatment with tannase and phytase (5 days). Treatments were performed at $30{ }^{\circ} \mathrm{C}$, and determinations made after the fifth and tenth days. All the procedures above were applied to the raw sorghum flour to be used as a blank.

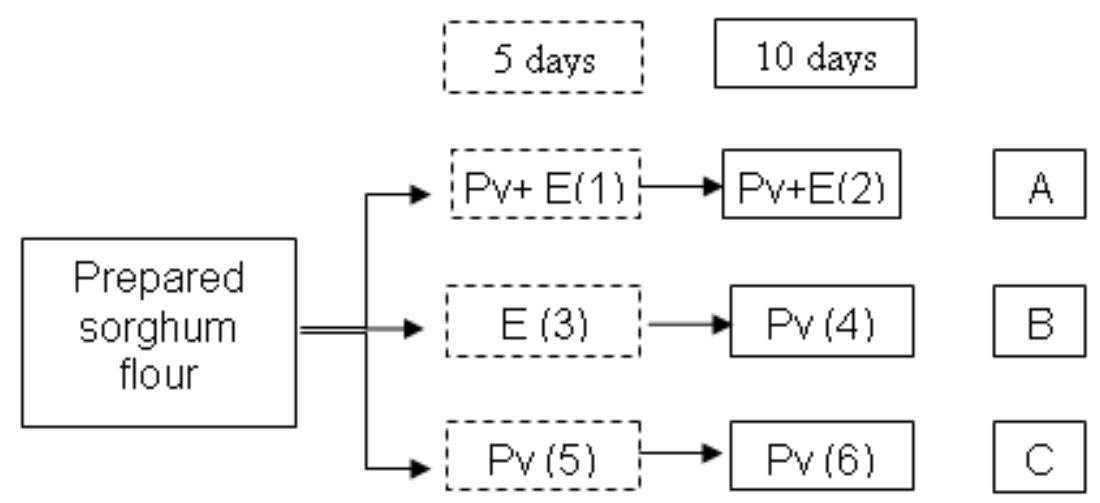

Figure 2. Treatments applied to the sorghum.

$\mathrm{Pv}=$ Paecilomyces variotii, $\mathrm{E}=$ tannase and phytase.

\section{Extraction and Quantification of Phenolic Compounds and}

\section{Tannins}

The extraction of phenolic compounds from the sorghum was accomplished by using a $200 \mathrm{mg}$ sample and $10 \mathrm{~mL}$ of methanol (ECIBRA) in a G2 model orbital shaker (EDISON) at $200 \mathrm{rpm}, 25^{\circ} \mathrm{C}$, for 2 hours. The extract obtained was centrifuged at $1,320 \mathrm{xg}$ at $5{ }^{\circ} \mathrm{C}$ for $15 \mathrm{~min}$. The determination of total phenols was carried out using the Follin-Ciocaulteau reagent (30). Hydrolysable tannins were determined using ferric ammonium sulphate (8) and condensed tannins were determined through the vanillin method (26). Quantification was done by plotting a calibration curve using gallic acid (SIGMA), tannic acid (MERCK) and catechin (SIGMA) as standards for total phenols, hydrolysable tannins and condensed tannins, respectively. The results were expressed in $\mathrm{mg} / 100 \mathrm{~g}$ of sorghum.

\section{Inorganic Phosphorus Quantification}

In order to measure the action of phytase on sorghum gruels a method that estimates the inorganic phosphorus released while the phytase is acting was chosen. The extraction was performed using $500 \mathrm{mg}$ of the sample and $10 \mathrm{~mL}$ of $0.5 \mathrm{M}$ 
$\mathrm{HCl}$ solution shaken for two hours in a $\mathrm{G} 2$ model orbital shaker (EDISON) at $200 \mathrm{rpm}$ and at room temperature $\left(25^{\circ} \mathrm{C}\right)$; after the extraction, the medium was centrifuged at $1,320 \mathrm{xg}, 5^{\circ} \mathrm{C}$, for 15 min (34). The extract obtained was used to determine inorganic phosphorus levels (30). The quantification was done using the calibration curve method with $\mathrm{K}_{2} \mathrm{HPO}_{4}$ and expressed in $\mathrm{mg} / 100 \mathrm{~g}$ of sorghum.

\section{Statistical Analysis}

Results from all experiments and analyses were expressed as the mean value \pm the standard deviation of the mean (SD). The means were submitted to variance analysis (ANOVA) and the Tukey test; the level of significance was stated at $P<0.1$ using STATISTICA 8.0 software.

\section{RESULTS AND DISCUSSION}

The methodologies employed in this work to determine phenolic compounds are highly variable and there are several ways to extract the compounds of interest. Furthermore, there is no consensus on the use of standards to prepare the calibration curve and that hampers the comparison of different studies as the values obtained may therefore be relative

\section{Tannase Activity Behavior}

The tannase employed had an activity of $626 \mathrm{U} / \mathrm{g}$ and a specific activity of $1.89 \mathrm{U} / \mathrm{mg}$ of protein. This high activity for tannase was expected since the composition of the medium was prepared by the addition of tannic acid inducer. According to Macedo et al., (20), Aguilar et al., (1); and Battestin, et al., (4), tannic acid acts both as a carbon source for the microorganism, and as an inducer of the endogenous synthesis of the enzyme.

In a study using KBR9 Bacillus cereus for the production of tannase by adding $10 \mathrm{~g} / \mathrm{L}$ of tannic acid to submerged culture medium, values of $0.22 \mathrm{U} / \mathrm{mL}$ (23) for the enzyme activity were obtained

\section{Effect of the Treatments upon Phenolic Content}

The amount of total assayable phenols (TP) has shown to be lower $(\mathrm{p}<0.1)$ after treatments A, B and C (for 5 days) compared to the untreated sorghum flour (Table 1). It was found that 5-day treatments were more effective in reducing TP than 10-day treatments. That tardy increase in TP content could be ascribed to the presence of foreign compounds formed over the extra period, since the Follin-Ciocaulteau reagent used is sensitive to any compound that is capable of reducing it, including proteins.

Therefore, it cannot be stated with certainty that the TP concentration verified on the tenth day could be assigned to phenolic compounds alone. Experiments 1, 3 and 5 showed the lowest concentration of TP, in which reductions of $48,48.5$ and 66 $\%$, were accomplished, respectively. Treatments carried out with $P$. variotii plus enzymes were also effective in reducing TP.

Table 1. Effect of enzymatic and fermentative treatments of sorghum flour on total phenols, hydrolysable tannins and condensed tannins.

\begin{tabular}{cccc}
\hline Treatments $^{\mathbf{b}}$ & $\mathbf{T P}^{\mathbf{a}}$ & $\mathbf{T H}^{\mathbf{a}}$ & $\mathbf{T C}^{\mathbf{a}}$ \\
\hline Sorghum Flour & $111.08 \pm 9.31 \mathrm{a}$ & $63.89 \pm 10.02 \mathrm{a}$ & $139.95 \pm 2.46 \mathrm{ab}$ \\
\hline \multicolumn{5}{c}{ Treatment A } \\
\hline Pv + E (1) & $57.66 \pm 0.06 \mathrm{cde}$ & $4.50 \pm 0.05 \mathrm{~b}$ & $147.6 \pm 0.15 \mathrm{a}$ \\
\hline \multicolumn{5}{c}{ Treatment B } & $6.66 \pm 4.16 \mathrm{~b}$ & $9.54 \pm 2.73 \mathrm{c}$ \\
\hline E (3) & $77.28 \pm 3.49 \mathrm{bc}$ & $8.33 \pm 1.21 \mathrm{~b}$ & $19.4 \pm 5.98 \mathrm{c}$ \\
E + PV (4) & $57.18 \pm 9.51 \mathrm{ec}$ & $3.18 \pm 0.04 \mathrm{~b}$ & $7.52 \pm 10.63 \mathrm{c}$ \\
\hline \multicolumn{5}{c}{ Treatment C } \\
\hline PV (5) & $77.22 \pm 11.49 \mathrm{bd}$ & $4.57 \pm 0.51 \mathrm{~b}$ & $98.62 \pm 10.43 \mathrm{ab}$ \\
\hline Pv + E (6) & $37.7 \pm 4.52 \mathrm{e}$ & $4.73 \pm 0.56 \mathrm{~b}$ & $84.43 \pm 11.97 \mathrm{~b}$ \\
\hline
\end{tabular}

Results in the same column followed by different letters (a-e) indicate statistically significant differences $(\mathrm{P}<0.1)$ by the Tukey Test. Pv: Paecilomyces variotii; E: tannase and phytase. TP: Total phenols; HT: Hydrolysable tannins; CT: Condensed tannins. ${ }^{a}$ Results expressed in $\mathrm{mg} / 100 \mathrm{~g}$ sorghum flour. ${ }^{\mathrm{b}}$ Treatments are demonstrated in Fig.2. 
Hydrolysable tannins (HT) were extensively reduced in all treatments of sorghum flour and no significant difference $(\mathrm{p}<0.1)$ among them was observed, however they were different from those of the raw sorghum; on the average that decrease was of $92 \%$. Hydrolysable tannins are largely reactive and instable compounds; they can be degraded by chemical, physical and biological methods $(27,2,21,37)$ so it cannot be asserted whether the decrease in HT has occurred either due to the addition of tannase or to the physical treatments such as soaking or heating.

Condensed tannins contents were lowered with less intensity. Only experiments 2, 3 and 4 showed statistically significant differences $(\mathrm{p}<0.1)$ when compared to raw sorghum values, representing a reduction of 93,86 and $95 \%$, respectively. The other treatments did not differ significantly $(\mathrm{p}<0.1)$ from raw sorghum values. Condensed tannins in Treatment 1 were not statistically different $(\mathrm{p}<0.1)$ from raw sorghum; however, another 5 days of fermentation (Treatment 2) reduced this compound by $93 \%$, probably as a result of $P$. variotii metabolism.

Towo et al., (34) demonstrated a reduction in total phenols, hydrolysable tannins and condensed tannins of 62, 72.3 and $81.3 \%$ respectively in sorghum treated with a combination of fermentation, polyphenoloxidase and phytase enzyme.

Matuschek et al., (22) studied the decrease in phenolics and phytate in sorghum with an application of polyphenoloxidase after cooking, soaking and germinating the grains. The study showed that the best result was verified with enzymatic treatment after germination, with decreases of 50 and $42 \%$ on HT and CT, respectively.

Studies have shown that microorganisms are able to degrade tannins with lower molecular weights and simple structures, such as hydrolysable tannins, better than the condensed ones, since the latter can be toxic to them. The main toxicity mechanisms in tannins are enzymatic inhibition, substrate deprivation, action on the microorganism membrane and linkage with metal ions. Despite the antimicrobial properties of tannins, many fungi, bacteria and yeast are quite resistant to tannins and still can grow and develop when they are present (7).

Microorganisms have been studied for their application in the biodegradation of tannins. Possibly, the $P$. variotii fungus employed has a similar action to those reported by Kumar et al., (18), who isolated Citrobacter freundii from tannery effluent and studied the pathway of tannic acid degradation by this microorganism. The highest tannase production (1.87 $\mathrm{U} / \mathrm{mL}$ ) was obtained in a medium containing $1 \%$ tannic acid, at $30^{\circ} \mathrm{C}$, after $6 \mathrm{~h}$. Tannic acid biodegradation followed this pathway: tannic acid (tannase) $\rightarrow$ glucose + gallic acid (decarboxylase) $\rightarrow$ pyrogallol (1,2-dioxygenase) $\rightarrow$ 2hydroxymuconic acid $\rightarrow$ pyruvate. Rodrígues et al., (28) studied the Lactobacillus plantarum pathway to hydrolyzed tannic acid. Tannic acid degradation by Lactobacillus plantarum implies gallic acid and glucose formation by tannase; the gallic acid formed is decarboxylated to pyrogallol by gallate decarboxylase. Auto degradation of tannic acid by $63 \%$ was also verified.

\section{Phosphorus Content After Treatment}

Untreated sorghum presents a phosphorus content of 125 $\mathrm{mg} / 100 \mathrm{~g}$ of sorghum, which has shown to increase after the application of almost all treatments 1, 2, 3, 4 and 6. The increases were of 70,113, 82, 108 and $19 \%$, respectively (Fig. 3 ). Experiments 2 and 4 showed the largest Pi content although they did not statistically differ from one another $(p<0.1)$. The increases in $\mathrm{Pi}$ are likely to be assigned to the action of the added phytase enzyme.

Many studies have demonstrated the action of exogenous phytase in phytate decrease and accompanying increases in penta-, tetra-, bis-, mono- phosphates and free phosphorus (22, $34)$. 


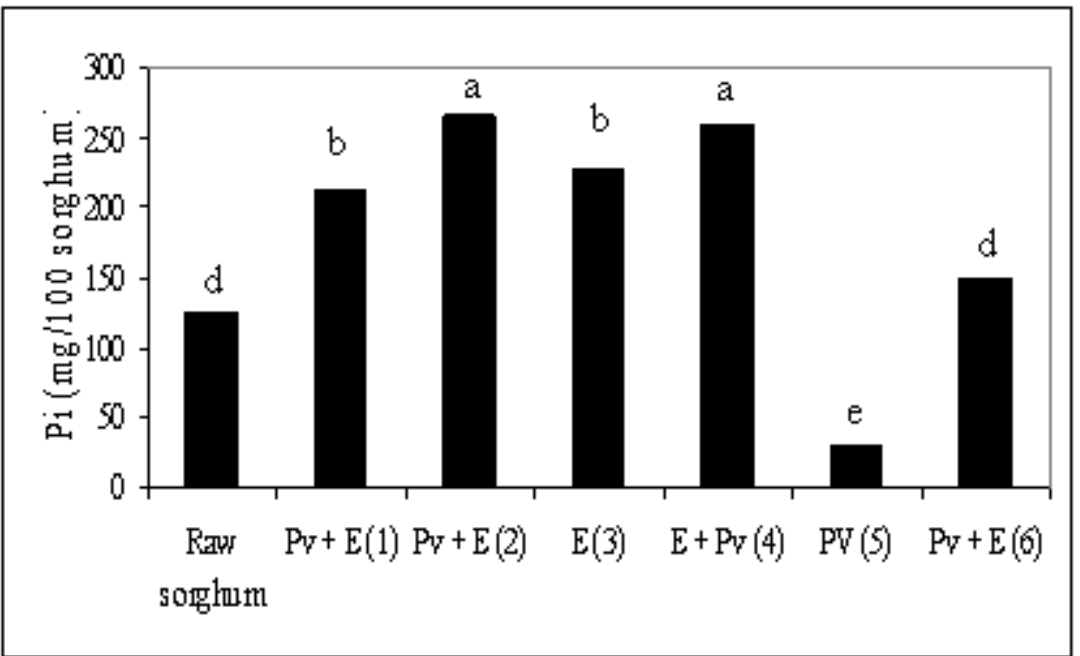

Figure 3. Inorganic phosphorus in raw sorghum and in sorghum treated with Paecilomyces variotii (Pv), tannase and phytase (E). Different letters indicate statistically significant differences $(\mathrm{P}<0.1)$.

Sorghum flour treated with $P$. variotii (Experiment 5) resulted in a marked reduction of inorganic phosphorus in the medium, which was of $76 \%$. That could be ascribed to the fact that the fungus might have used for its growth both the innate $\mathrm{Pi}$ and the Pi released from phytate.

Some studies have claimed that a lactic acid bacteria can break down phytate when it is the only phosphorus source in the medium (19). Bergqvist et al., (6) verified that a decreased level of soluble minerals may be attributed to their being involved in various functions in the lactic acid bacteria themselves. Kayodé et al., (16) attribute the reduction in phytate to lactic acid bacteria and yeasts, which can produce phytase and thus degrade phytate into its lower form, $\mathrm{IP}_{5}$ (inositol-pentakisphophate), $\mathrm{IP}_{4}$, etc., and inorganic phosphorus (Pi) and which is used then for its growth.

Comparing treatments $\mathrm{B}$ and $\mathrm{C}$ we can say that the treatment order ( $P$. variotii versus enzymes) influenced the measured parameters, especially the $P$. variotii treatment on the final concentration of $\mathrm{Pi}$.

Among the proposed treatments we noted that the best results, decrease in tannin and increase in $\mathrm{Pi}$, occurred in experiments 2, 3 and 4. However, it must be pointed that the $P$. variotii uses $\mathrm{Pi}$ for its growth. In addition, this fungus has only been selected recently and has not been subjected to analysis of acute toxicity in vivo and is not considered GRAS (Generally Recognized as Safe). According to Graminha et al., (13) the production of mycotoxins can be a limiting factor when employing microorganism that are not considered GRAS.

The fermentation and enzyme and combination of fermentation- enzyme treatments studied were effective in diminishing tannin and phytate in sorghum flour, so this treatment can be used to increase the nutritive value of sorghum grains destined for animal feeds or human nutrition. Future studies should be made in order to optimize the enzymatic treatment.

\section{ACKNOWLEDGEMENTS}

This research was supported by the State of São Paulo Research Foundation (Fundação de Amparo à Pesquisa do Estado de São Paulo: FAPESP), and the University of Campinas - UNICAMP, São Paulo - Brazil. 


\section{REFERENCES}

1. Aguilar, C.N.; Augus, C.; González, G.V.; Favela, E. (1999). A comparison of methods to determine tannin acyl hydrolase activity. Braz. Arch. Biol. Techn. 42, 355-361.

2. Ali, N.M.M.; El Tinay, A.H.; Elkhalifa, A.E.; Salih, O.A.; Yousif, N.E. (2009). Effect of alkaline pretreatment and cooking on protein fractions of a high-tannin sorghum cultivar. Food Chem. 114, 649-651.

3. Bajpai, B.; Patil, S. (2008). A new approach to microbial production of gallic acid. Braz. J. Microbiol. 39, 708-711.

4. Battestin, V.; Macedo, G.A. (2007). Tannase production by Paecilomyces variotii. Bioresource Technol. 98, 1832-1837.

5. Battestin, V.; Macedo, G.A.; Freitas, V.A.P. (2008). Hydrolysis of epigallocatechin gallate using a tannase from Paecilomyces variotii. Food Chem. 108, 228-233.

6. Bergqvist, S.W.; Sandberg, A.S.; Carlsson, N.G.; Andlid, T. (2005) Improved iron solubility in carrot juice fermented by homo- and heterofermentative lactic acid bacteria. Food Microbiol. 22, 53-61.

7. Bhat, T.K.; Singh, B.; \& Sharma, O.P. (1998). Microbial degradation of tannins: a current perspective. Biodegradation. 9, 343-357.

8. Brune, M.; Hallberg, L.; Skanberg, A. B. (1991). Determination of ironbinding phenolic groups in foods. J. Food Sci. 56, 128-131.

9. Butolo, J. E. (2002). Qualidade de ingredientes na alimentação animal. Ed. Oesp Gráfica S/A. Campinas - São Paulo. 430p.

10. Correia, I.; Nunes, A.; Duarte, I.F.; Barros, A.; Delgadillo, I. (2005). Sorghum fermentation followed by spectroscopic techniques. Food Chem. 90, 853-859.

11. Elmaki, H. B.; Babiker, E. E.; El Tinay, A. H. (1999). Changes in chemical composition, grain malting, starch and tannin contents and protein digestibility during germination of sorghum cultivars. Food Chem. 64, 331-336.

12. Garcia-Conesa, M.T.; Ostergaard, P.; Kauppinen, S.; Williamson, G. (2001). Hydrolysis of diethyl diferulates by tannase from Aspergillus oryzae. Carbohyd. Polym. 44, 319-324.

13. Graminha, E.B.N.; Gonçalves, A.Z.L.; Pirota, R.D.P.B.; Balsalobre, M.A.A.; Silva, R.; Gomes, E. (2008). Enzyme production by solid-state fermentation: application to animal nutrition. Anim. Feed Sci. Tech. 144, $1-22$.

14. Haslam, E. (1966). Chemistry of vegetable tannins. Academic Press, London.

15. Hassan, I.A.G.; El Tinay, A.H. (1995). Effect of fermentation on tannin content and in-vitro protein and starch digestibility of two sorghum cultivars. Food Chem. 53, 149-151.

16. Kayodé, A.P.P.; Hounhouigan, J.D.; Nout, M.J.R. (2007). Impact of brewing process operation on phytate, phenolic compounds and in vitro solubility of iron and zinc in opaque sorghum beer. Lebensm. Wiss.
Technol. 40, 834-841.

17. Konietzny, U.; Greiner, R. (2004). Bacterial phytases: potential application, in vivo function and regulation of its synthesis. Braz. J. Microbiol. 35, 11-18.

18. Kumar, R.A.; Gunasekaran, P.; Lakshmanan, M. (1999). Biodegradation of tannic acid by Citrobacter freundii isolated from a tannery effluent. $J$. Basic Microb. 39, 161-168.

19. Lopez, H.W.; Ouvry, A., Bervas, E.; Guy, C.; Messager, A.; Demingue, C.; Remesy, C. (2000). Strains of lactic acid bacteria isolated from sour doughs degrade phytic acid and improve calcium and magnesium solubility from whole wheat flour. J. Agr. Food Chem. 48, 2281-2285.

20. Macedo, G.; Matsuda, L.K.; Battestin, V. (2005). Seleção de fungos produtores de tanase em resíduos vegetais. Ciência e Agrotecnol. 29, 833 838.

21. Mahgoub, S. E. O.; Elhag, S. A. (1998). Effect of milling, soaking, malting, heat-treatment and fermentation on phytate level of four Sudanese sorghum cultivars. Food Chem. 61, 77-80.

22. Matuschek, E.; Towo, E.; Svanberg, U. (2001). Oxidation of polyphenols in phytate-reduced high-tannin cereals: effect on different phenolic groups and on in vitro accessible iron. J. Agr. Food Chem. 49, 56305638.

23. Mondal, K.C.; Banerjee, D.; Jana, M.; Pati, B.R. (2001). Colorimetric assay method for determination of the tannin acyl hidrolase activity. Anal. Biochem. 295, 168-171.

24. Pandey, A.; Szkacks, G.; Soccol, C.R.; Rodriguez-Leon, J.A.; Soccol, V.T. (2001). Production, purification and properties of microbial phytases. Bioresource Technol. 77, 203-214.

25. Porres, J.M.; Aranda, P.; López-Jurado, M.; Urbano, G. (2008). Effect of hydroalcolic $\alpha$-galactoside extraction and phytase supplementation on the nutritive utilisation of manganese, iron, zinc and potassium from lupin (Lupins albuns var. multolupa)-based diets in growing rats. Food Chem. 109, 554-563.

26. Price, M.L.; Van S.S.; Butler, L.G. (1978). A critical evaluation of the vanillin reaction as an assay for tannin in sorghum grain. J. Agr. Food Chem. 26, 1214-1218.

27. Rakic, S.; Petrovic, S.; Kukic, J.; Jadranin, M.; Tesevic, V.; Povrenovic, D.; Siler-Marinkovic, S. (2007). Influence of thermal treatment on phenolic compounds and antioxidant properties of oak acorns from Serbia. Food Chem. 104, 830-834.

28. Rodríguez, H.; Rivas, B.; Gómez-Cordovés, C.; Munõz, R. (2008). Degradation of tannic acid by cell-free extracts of Lactobacillus plantarum. Food Chem. 107, 664-670.

29. Selwal, M.K.; Yadav, A.; Selwal, K.K.; Aggarwal, N.K.; Gupta, R.; Gautam, S. K. (2011). Tannase production by Penicillium atramentosum KM under SSF and its applications in wine clarification and tea cream solubilization. Braz. J. Microbiol. 42, 374-387. 
30. Shimizu, M. (1992). Purification and characterization of Phytase from Bacillus subtilis (natto) N-77. Biosci. Biotech. Bioch. 56, 1266-1269.

31. Slva, J. B.;Dilkin, P.; Fonseca, H.; Correa, B. (2004). Production of aflatoxins by Aspergillus flavus and Fumonisins by Fusarium species isolated from Brazilian sorghum. Braz. J. Microbiol. 35, 182-186.

32. Singleton, V.L.; Rossi. J.A. (1965). Colorimetry of total phenolic with phosphomolybdic-phosphotungstic acid reagents. Am J. Enol. Viticult. $16,144-158$

33. Srivastava, A.; Kar, R. (2009). Characterization and application of tannase produced by Aspergillus niger ITCC 6514.07 on pomegranate rind. Braz. J. Microbiol. 40, 782-789.

34. Towo, E.; Matuschek, E.; Svanberg, U. (2006). Fermentation and enzyme treatment of tannin sorghum gruels: effects on phenolic compounds, phytate and in vitro accessible iron. Food Chem. 94, 369-376.

35. Urbano, G.; Porres, J.M.; Frejnagel, S.; López-Jurado, M.; GómezVillalva, E.; Vidal-Valverde, C.; Aranda, P. (2007). Improvement of iron availability from phytase-treated Pisum sativum, L. flour. Food Chem.103, 89-395.

36. Vats, P.; Banerjee, U.C. (2004). Production studies and catalytic properties of phytases (myo-inositolhexakisphosphate phosphohydrolases): an overview. Enzyme Microb. Tech. 35, 3-14.

37. Xu, B.; Chang, S.K.C. (2008). Effect of soaking, boiling and steaming on total phenolic content and antioxidant activities of cool season food legumes. Food Chem. 110, 1-13.

38. Youssef, A. M. (1998). Extractability, fractionation and nutritional value of low and high tannin sorghum proteins. Food Chem. 63, 325-329.

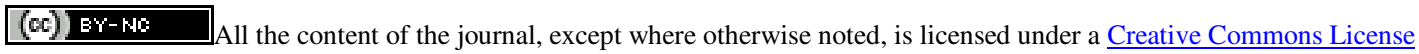

